\title{
Teocomunicação
}

Revista de Teologia da PUCRS

Programa de Pós-Graduação em Teologia

Escola de Humanidades

Porto Alegre, v. 48, n. 2, p. 262-264, julho-dezembro 2018

http://dx.doi.org/10.15448/0103-314X.2018.2.32625

RESENHA

\section{REGOLI, Roberto. Oltre la crisi della Chiesa. II pontificado di Benedetto XVI. Torino: Lindau, 2016. 502 p.}

\section{Geraldo Luiz Borges Hackmann*}

O autor, professor de História da Igreja na Pontifícia Universidade Gregoriana, de Roma, e editor da revista Archivum Historiae Pontificiae, escreve a presente obra com o intuito de estudar e aprofundar as orientações do pontificado do Papa Bento XVI a partir de suas encíclicas, alocuções e discursos - não em todos, mas aqueles que marcaram época, como o de Regensburg, em 2006 - assim como em nomeações, em algumas viagens e audiências, mas, principalmente, no estilo de seu governo e nos momentos de crise (p. 7 e 8). Estas fontes são estritamente públicas, visto que o Arquivo Secreto ainda não está aberto, pois é um papado recente. Assim, a obra está sujeita a duas lógicas: "a história imediata da atualidade e dos longos tempos da historiografia" (p.9). Mas o autor adverte que as páginas do livro não se confundem com jornalismo, porquanto o historiador, ao seguir o método histórico de pesquisa, tem o privilégio de ter vivido o que escreve e como se conclui o que está sendo descrito, além de não ocultar as dimensões espirituais e religiosas dos acontecimentos relatados, não se deixando guiar pelos esquemas duais direita/esquerda e conservador/progressista (p. 10). Ainda declara que também não deseja oferecer uma biografia do Papa Bento XVI, mas apresentar um esboço da história de seu pontificado, que abrangeram anos decisivos para o catolicismo contemporâneo (p. 11).

O que torna significativo o pontificado de Bento XVI não é apenas a sua conclusão imprevista, por causa da renúncia e a criação do Papa emérito, mas principalmente questões deixadas abertas e ainda não concluídas, pois Bento XVI abriu diversos pontos centrais para a vida da Igreja, tais como o espaço dado à posições do Vaticano II até então marginalizadas, as relações ecumênicas (a novidade do ordinariato pessoal para os Anglicanos, criado conjuntamente com a Igreja Anglicana), as relações com outras religiões e questões relativas à eclesiologia.

A obra está dividida em oito capítulos: o conclave e o programa do pontificado (1), a cúria romana (2), o governo magisterial da Igreja (3), a urgência do governo universal (4), a unidade dos cristãos (5), o diálogo com a cultura (6), a diplomacia pontifícia (7) e a renúncia ao ministério petrino (8). No final, além da conclusão e da cronologia do

\footnotetext{
* Doutorado em Teologia pela Pontificia Università Gregoriana (1990). Pós-Doutorado pelo Institut Catholique de Toulouse, França (2012). Atualmente é professor do Curso de Teologia da Pontifícia Universidade Católica do Rio Grande do Sul.<gborgesh@pucrs.br>
} 
pontificado de Bento XVI, o autor apresenta uma longa lista de fontes (23 páginas) e de bibliografia (27 páginas) usadas para fundamentar sua análise do pontificado em destaque.

Segundo o autor, a fé é o tema central do pontificado de Bento XVI. Desde antes de sua eleição, ele já estava consciente da crise de fé que assolava não só a Europa, mas também o mundo. Por isso, ele se referia inúmeras vezes à "ditadura do relativismo", que, para ele, é consequência da perda da fé, fruto da mudança cultural acontecida no pensamento ocidental. Este aspecto diz respeito a relação entre a Igreja e o mundo e não apenas aos já membros da Igreja Católica (cf. p. 31). Por isso, ele conclama a Igreja ao Ano da Fé, como tentativa de dar uma resposta a este desafio próprio do mundo atual, além de propor a mesma temática em suas encíclicas, na obra Jesus de Nazaré e em outras ocasiões (p. 119-124).

Diferentemente de outros pontífices, Bento XVI não escreveu uma encíclica programática, como, por exemplo, fez o seu antecessor, o Papa João Paulo II, com a carta encíclica Redemptor Hominis (1979). O autor considera que a direção do novo pontificado foi dada pelas homilias das celebrações eucarísticas com os cardeais eleitores, no dia 20 de abril de 2005, e com a de abertura do novo pontificado, no dia 24 de abril (p. 53).

O autor considera que o Papa Bento XVI fez marcantes e profundas mudanças no Cúria Romana, de acordo com as urgências e prioridades da Igreja e do papado, apesar de discretas, seguindo seu temperamento. Ele fez gradativas alterações nos dicastérios, promovendo mudanças que obedeceram ao tempo natural de término do serviço prestado. Além disso, não houve o privilégio de um grupo nacional ao qual ele pertencia - o alemão, no caso, mas há a superação da pertença geográfica a favor do compartilhar de um projeto, de uma mesma visão de conjunto (p. 60).

O estilo de governo de Bento XVI também é próprio. Ele estuda minuciosamente os dossiês que lhe são entregues, enfrentando maior dificuldade para decidir sobre pessoas, como ele mesmo afirma (p.73). Ele recebia sistematicamente seus colaboradores mais próximos, como os Prefeitos das Congregações. Suas audiências foram sempre protocolais e não usava os cafés matinais ou almoços para encontrar seus colaboradores ou outras pessoas, diferentemente de seu antecessor (p. 72 e 73). Uma de suas dificuldades em relação à Cúria romana foi a nomeação do Cardeal Bertone como Secretário de Estado, pois ele não pertencia à carreira diplomática, causa de muitas tensões e que provocou a necessidade de reafirmar a sua confiança nele em uma carta dirigida ao Secretário de Estado por ocasião de seus 75 anos e publicada no L'Osservatore Romano do dia 22 de janeiro de 2010, assim como outra por ocasião de seu jubileu de ouro de ordenação presbiteral, no dia 30 de junho de 2010, também publicada no mesmo jornal (p. 79-82).

Outro ponto destacado pelo autor é a luta contra os abusos de menores praticados por membros do clero, por meio de diversas iniciativas para combater a crise da pedofilia, implantando a política de tolerância zero e reconhecendo a culpa por parte daqueles que praticaram os abusos ou foram coniventes com eles. O caso emblemático é o de marcial Maciel Degollado, fundador dos Legionários de Cristo (p. 171-189). A destacar, ainda, e a promoção da unidade dos cristãos, primeiro dentro da própria Igreja Católica (p. 215-222), depois com os seguidores de Marcel Lefrebve e o mundo tradicionalista (p.222-244), com os anglicanos, por meio da Constituição Anglicanorum Coetibus, que gerou vários ordinariatos pessoais (p.245-263), e, por fim, com os ortodoxos (p. 263-273). Destaca-se, ainda, o diálogo com a cultura (p.280-330) e as relações diplomáticas com diversos países, incluindo a China (p. 331-383). 
Entre as abundantes fontes da pesquisa citadas nas 936 notas de rodapé, destacam-se as citações aos diversos escritos de próprio Papa Bento XVI, sejam de ordem teológica quanto magisterial, as do jornalista Gianluigi Nuzzi e a obra, muitas vezes indicada, de Marco Politi (Joseph Ratzinger. Crisi di un papato. Bari: Laterza, 2013).

A leitura do livro propicia uma visão geral sobre o pontificado do Papa Bento XVI, alargando o horizonte de interpretação do pontificado que teve um fim inesperado, com a sua renúncia, anunciada no dia 11 de fevereiro de 2013, além de também oferecer uma narração dos diversos acontecimentos que fizeram deste pontificado um momento inesquecível para a Igreja e para o mundo, não só por apresentar o que de positivo aconteceu para a vida da Igreja Católica, mas também ao abordar suas vicissitudes e crises.

\section{REFERÊNCIAS}

BENTO XVI. Jesus de Nazaré: do Batismo no Jordão à Transfiguração. São Paulo: Planeta do Brasil, 2007. 2011

Jesus de Nazaré: da entrada em Jerusalém até a ressurreição. São Paulo: Planeta do Brasil, . A infância de Jesus. São Paulo: Planeta do Brasil, 2012.

. Carta ao Secretário de Estado por ocasião de seus 75 anos. Jornal L'Osservatore Romano,

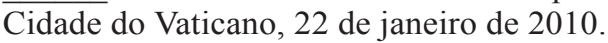

Carta ao Secretário de Estado por ocasião de seu jubileu de ouro de ordenação presbiteral. Jornal L'Osservatore Romano, Cidade do Vaticano, 30 de junho de 2010.

JOÃO PAULO II. Carta encíclica Redemptor Hominis (04.03.1979). São Paulo: Paulinas, 1979.

POLITI, Marco. Joseph Ratzinger. Crisi di un papato. Bari: Laterza, 2013.

REGOLI, Roberto. Oltre la crisi della Chiesa. Il pontificado di Benedetto XVI. Torino: Lindau, 2016. 502p.

Recebido em: 29/11/2018

Aprovado em: 30/11/2018

\section{Correspondência para:}

Dr. Pe. Geraldo Luiz Borges Hackmann

Paróquia N. Sa de Lourdes

Rua General Caldwell, 1022 - Azenha

CEP 90130-050 Porto Alegre, RS, Brasil 